Jurnal Penelitian dan Pengabdian Kepada Masyarakat Bidang ilmu Pendidikan

\title{
Guru Profesional, Mutu Pendidikan dan Tantangan Pembelajaran
}

\author{
Ilyas Yasin \\ Program Studi Pendidikan Sejarah, STKIP Yapis Dompu \\ E-mail: ilyascendekia@gmail.com
}

Article History: Received: 2022-01-11 || Revised: 2022-02-01 || Published: 2022-02-22

Sejarah Artikel : Diterima: 2022-01-11 || Direvisi: 2022-02-01 || Dipublikasi: 2022-02-22

\begin{abstract}
This research is a qualitative research with literature review, qualitative research is a study used to examine natural objects where the researcher is the key instrument, data collection techniques are combined, data analysis is inductive, and qualitative research results emphasize meaning rather than generalization. Overall, there are many factors that influence the quality of education, both culturally and structurally, from students, teachers, facilities, funding to policies. Ideally these two factors should go hand in hand to improve the quality of education, but in fact this is not always the case. This paper will describe the problem of improving the quality of education, especially with regard to teachers. As the main agent of learning, teachers are very decisive in encouraging the transformation of education in the midst of various existing limitations. On the other hand, no matter how good education policies are made without the support of dedicated and professional teachers, not much change can be expected to occur.
\end{abstract}

Keywords: Teacher, professional, Quality, School.

\begin{abstract}
Abstrak
Penelitian ini merupakan penelitian Kualitatif dengan Kajian Pustaka, penelitian kualitatif merupakan suatu penelitian yang digunakan untuk meneliti pada objek yang alamiah dimana peneliti adalah sebagai instrumen kunci, teknik pengumpulan data dilakukan secara gabungan, analisis data bersifat induktif, dan hasil penelitian kualitatif lebih menekankan makna daripada generalisasi, Secara keseluruhan ada banyak faktor yang memengaruhi mutu pendidikan baik secara kultural maupun struktural sejak dari siswa, guru, fasilitas, pembiayaan hingga kebijakan. Idealnya kedua faktor tersebut harus berjalan bersamaan untuk meningkatkan mutu pendidikan, tapi faktanya tidak selalu demikian. Tulisan ini akan membentangkan problem peningkatan mutu pendidikan khususnya berkaitan dengan guru. Sebagai agen utama pembelajaran guru sangat menentukan dalam mendorong transformasi pendidikan di tengah berbagai keterbatasan yang ada. Sebaliknya, sebagus apapun kebijakan pendidikan dibuat tanpa didukung oleh guru-guru yang berdedikasi dan profesional maka tidak banyak perubahan yang dapat diharapkan akan terjadi.
\end{abstract}

Kata kunci: Guru, Profesional, Mutu, Sekolah.

\section{PENDAHULUAN}

Dalam menghadapi era kompetisi global dewasa ini, upaya untuk meningkatkan kualitas sumberdaya manusia (SDM) melalui pendidikan telah menjadi salah satu isu pokok yang dihadapi semua negara. Negara-negara di dunia kini saling berlomba dan berjuang keras untuk menyiapkan kualitas SDM terbaiknya guna memenangkan persaingan tersebut. Dalam kompetisi global, pertarungan masa depan dan eksistensi sebuah bangsa tidak lagi ditentukan oleh ketersediaan sumberdaya alam yang melimpah (natural resources) tapi sangat bergantung pada keunggulan SDM-nya (human resources). Oleh karena itu, untuk memenangkan persaingan tersebut maka tidak ada pilihan lain kecuali melakukan investasi sebesar-besarnya di bidang pendidikan. Dengan demikian, sebagai investasi strategis, maka peningkatan kualitas SDM melalui pendidikan tidak sekadar kebutuhan tapi bahkan akan ikut menentukan survive sebuah bangsa di masa depan, Jika dilihat dari konteks pendidikan nasional, maka agenda peningkatan mutu pendidikan tersebut makin mendesak karena sejumlah hasil survei dan penelitian menunjukkan bahwa Indeks 
Pembangunan Manusia (IPM) Indonesia masih sangat rendah, bahkan di kawasan Asia Tenggara. Oleh karena itu, untuk merespon tantangan tersebut maka pemerintah khususnya setelah era reformasi, telah melakukan beberapa terobosan penting sebagai bagian dari reformasi dunia pendidikan baik menyangkut visi, regulasi, kebijakan, strategi hingga pembiayaan pendidikan. Dalam hubungan ini, secara operasional pemerintah telah menetapkan bahwa strategi dan prioritas pembangunan pendidikan nasional diarahkan pada tiga hal pokok yaitu (1) pemerataan dan perluasan akses pendidikan, (2) peningkatan mutu, relevansi dan daya saing; dan (3) penguatan tatakelola, akuntabilitas, dan citra publik (Depdiknas, 2005).

\section{METODE PENELITIAN}

Penelitian ini merupakan penelitian Kualitatif dengan Kajian Pustaka, penelitian kualitatif merupakan suatu penelitian yang digunakan untuk meneliti pada objek yang alamiah dimana peneliti adalah sebagai instrumen kunci, teknik pengumpulan data dilakukan secara gabungan, analisis data bersifat induktif, dan hasil penelitian kualitatif lebih menekankan makna daripada generalisasi. Penelitian kualitatif bertujuan mempertahankan bentuk dan isi perilaku manusia dan menganalisis kualitas-kualitasnya, alih-alih mengubahnya menjadi entitas-entitas kuantitatif (Mulyana, 2008: 150), tujuan dari penelitian deskriptif ini adalah untuk membuat deskipsi, gambaran atau lukisan secara sistematis, faktual dan akurat mengenai fakta-fakta, sifat-sifat serta hubungan antar fenomena yang diselidik, adapun sumber data yang dijadikan acuan dalam penelitian ini diantaranya Referensi-referensi pustaka yang bersumber dari literature terkait dengan problem guru professional dan mutu Pendidikan.

\section{HASIL DAN PEMBAHASAN}

\section{Kompetensi Guru}

Salah satu kebijakan strategis yang kini dilakukan untuk meningkatkan mutu pendidikan tersebut adalah disahkannya Undang-Undang Nomor 14 Tahun 2005 tentang Guru dan Dosen (UU GD) dan Peraturan Pemerintah Nomor 19 Tahun 2005 tentang Standar Nasional Pendidikan (SNP). Lahirnya regulasi tersebut telah membawa harapan baru bagi perbaikan dan peningkatan mutu pendidikan nasional. Secara spesifik, salah satu aspek menarik yang mendapat perhatian dari regulasi tersebut adalah mulai adanya political will pemerintah terhadap peningkatan mutu tenaga pendidik (guru) sebagai sebagai bagian dari peningkatan mutu pendidikan nasional khususnya pada jenjang pendidikan dasar dan menengah. Secara substansial, regulasi tersebut tidak hanya berisi tentang hak-hak dan kewajiban guru tapi yang lebih penting juga adalah mengatur dan menetapkan sejumlah kriteria dan syarat yang harus dimiliki tenaga pendidik. Sebagai pendidik profesional, guru diharuskan memiliki sejumlah kompetensi tertentu guna menunjang kelancaran tugas-tugas profesionalnya. Kompetensi adalah seperangkat pengetahuan, ketrampilan, dan perilaku yang harus dimiliki, dihayati, dan dikuasai oleh guru atau dosen dalam melaksanakan tugas keprofesionalan. Dalam pasal 39 ayat (2) Undang-Undang Sisdiknas dijelaskan bahwa pendidik bertugas merencanakan dan melaksanakan proses pembelajaran, menilai hasil pembelajaran, melakukan pembimbingan dan pelatihan, serta melakukan penelitian dan pengabdian kepada masyarakat, terutama bagi pendidik pada perguruan tinggi.

Mengingat tugas-tugas guru yang demikian kompleks, maka (calon) guru harus memiliki persyaratan tertentu. Menurut ketentuan pasal 28 ayat (1) PP SNP, pendidik harus memiliki persyaratan seperti kualifikasi akademik dan kompetensi sebagai agen pembelajaran, sehat jasmani dan rohani, serta memiliki kemampuan untuk mewujudkan tujuan pendidikan nasional. Sedangkan kompetensi dasar yang harus dimiliki guru yaitu kompetensi pedagogik, kepribadian, profesional, dan sosial. Dengan regulasi tersebut di atas, maka di samping diharapkan akan melahirkan guru-guru yang profesional juga dapat memberikan perlindungan terhadap guru baik secara hukum, profesional, keamanan dan kenyamanan dalam menjalankan tugas maupun jaminan kesejahteraan.

Peningkatan kompetensi akademik dan profesional guru sangat penting dilakukan karena mengajar merupakan aktivitas yang melibatkan proses-proses mental yang kompleks baik bersifat pedagogis, psikologis, dan didaktis. Aspek pedagogis menunjuk pada kenyataan bahwa mengajar di sekolah berlangsung dalam lingkungan pendidikan, karena itu guru harus 
mendampingi peserta didik menuju kesuksesan belajar atau kedewasaan. Aspek psikologis menunjuk pada kenyataan bahwa peserta didik yang belajar pada umumnya memiliki taraf perkembangan yang berbeda satu dengan lainnya, sehingga menuntut materi yang berbeda pula. Demikian halnya kondisi peserta didik, kompetensi, dan tujuan yang harus mereka capai juga berbeda. Sedangkan aspek didaktik menunjuk pada kenyataan bahwa proses belajar itu sendiri mengandung variasi, seperti belajar menghafal, belajar ketrampilan, belajar motorik, belajar konsep, belajar sikap, dan seterusnya (E. Mulyasa, 2008b: 20-21), selain itu, sebagai satu bidang pekerjaan khusus, profesi guru (dan dosen) menurut ketentuan pasal 7 ayat (1) UU No 14/2005 tentang Guru dan Dosen, harus dilaksanakan berdasarkan prinsip-prinsip profesionalitas yaitu (a) memiliki bakat, minat, panggilan jiwa, dan idealisme; (b) memiliki komitmen untuk meningkatkan mutu pendidikan, keimanan, ketakwaan, dan akhlak mulia; (c) memiliki kualifikasi akademik dan latar belakang pendidikan sesuai dengan bidang tugas; (d) memiliki kompetensi yang diperlukan sesuai dengan bidang tugas; (e) memiliki tanggung jawab atas pelaksanaan tugas keprofesionalan; (f) memperoleh penghasilan yang ditentukan sesuai dengan prestasi kerja; (g) memiliki kesempatan untuk mengembangkan keprofesionalan secara berkelanjutan dengan belajar sepanjang hayat; (h) memiliki jaminan perlindungan hukum dalam melaksanakan tugas keprofesionalan; dan (i) memiliki organisasi profesi yang mempunyai kewenangan mengatur hal-hal yang berkaitan dengan tugas keprofesionalan guru. Adapun kompetensi profesional guru, menurut pasal 3 ayat (7) PP Nomor 74/2008 tentang Guru, merupakan kemampuan guru dalam menguasai pengetahuan bidang ilmu pengetahuan, teknologi, dan/atau seni dan budaya yang diampunya yang sekurang-kurangnya meliputi penguasaan (a) materi pelajaran secara luas dan mendalam sesuai dengan standar isi program satuan pendidikan, mata pelajaran, dan/atau kelompok mata pelajaran yang akan diampu; dan (b) konsep dan metode disiplin keilmuan, teknologi, atau seni yang relevan, yang secara konseptual menaungi atau koheren dengan program satuan pendidikan, mata pelajaran, dan/atau kelompok mata pelajaran yang akan diampu.

Sedangkan standar kompetensi profesional guru pada jenjang pendidikan dasar dan menengah menurut Permendiknas No. 16/2007 tentang Standar Kualifikasi Akademik dan Kompetensi Guru adalah: (a) menguasai materi, struktur, konsep, dan pola pikir keilmuan yang mendukung mata pelajaran yang diampu; (b) menguasai standar kompetensi dan kompetensi dasar mata pelajaran/bidang pengembangan yang diampu; (c) mengembangkan materi pembelajaran yang diampu secara kreatif; (d) mengembangkan keprofesionalan secara berkelanjutan dengan melakukan tindakan reflektif; dan (e) memanfaatkan teknologi informasi dan komunikasi untuk berkomunikasi dan mengembangkan diri. Sementara itu, berkaitan dengan kompetensi akademik, pasal 29 ayat (3) dan (4) PP SNP mensyaratkan bahwa pendidik pada jenjang pendidikan dasar dan menengah harus memiliki kualifikasi akademik minimum diploma IV (D-IV) atau sarjana (S1), latar belakang pendidikan yang sesuai dengan mata pelajaran yang diajarkan, dan memiliki sertifikasi guru. Sedangkan uji kualifikasi akademik dan kompetensi guru tersebut (sertifikasi) dikembangkan oleh Badan Standar Nasional Pendidikan (BSNP).

\section{Kondisi Guru}

Keharusan peningkatan kualifikasi akademik guru tersebut memang mendesak karena sebagian besar tingkat pendidikan guru pada jenjang pendidikan dasar dan menengah di Indonesia masih rendah atau di bawah standar. Untuk mengatasi permasalahan tersebut, sejak tahun 1992/1993 pemerintah telah melakukan program penyetaraan untuk guru SD hingga setara diploma dua (D-II) dan guru SMP setara D-III. Sampai tahun 1995 dari 1,2 juta guru SD sebanyak $78 \%$ atau 900 ribu belum berkualifikasi D-II. Jumlah guru SD yang mengikuti program penyetaraan D-II sampai tahun 1998 baru mencapai sekitar 320 ribu dan masih tersisa 590 ribu. Dengan rata-rata keikutsertaan program penyetaraan D-II tiap tahun sebanyak 20 ribu, maka untuk 590 ribu diperlukan waktu sekitar 30 tahun. Di tingkat SMP, sekitar 65 ribu guru telah mengikuti program penyetaraan D-III. Pada 1997 masih terdapat sekitar 75 ribu guru SMP yang perlu mengikuti program D3 yang latar belakang pendidikan terakhirnya SMA sampai D-II. Jika setiap tahun tersedia anggaran pemerintah untuk sekitar 8.000 guru, maka diperlukan waktu sekitar 10 tahun untuk menyelesaikan program ini. Adapun di tingkat SMA tingkat pendidikan 
guru relatif lebih baik karena pada 1997 sebanyak 66\% guru telah berkualifikasi S1 (Arifin, 2007).

Adanya tuntutan sertifikasi dan peningkatan kompetensi guru, khususnya kompetensi akademik dan profesional, tidak lain dimaksudkan untuk meningkatkan mutu proses maupun hasil pembelajaran. Sebagai agen pembelajaran (agent of learning) maka guru memainkan peranan penting dalam proses pembelajaran. Itulah sebabnya, salah satu ciri sekolah yang bermutu sebagaimana penelitian Cheng dan Wong di Cina ( E. Mulyasa, 2008a: 9) adalah ditandai oleh profesionalisme mengajar guru. Sedangkan ciri lainnya adalah (1) adanya dukungan pendidikan yang konsisten dari masyarakat; (2) adanya tradisi jaminan mutu (quality assurance) dari sekolah; dan (3) adanya harapan yang tinggi dari siswa untuk berprestasi. Kalau dikaitkan dengan kondisi guru saat ini maka beberapa standar kompetensi yang diharapkan sebagaimana tersebut di atas masih jauh dari harapan. Hal itu disebabkan kondisi objektif guru dewasa ini cukup kompleks karena tidak hanya berkaitan dengan kualifikasi akademik tapi juga distribusi guru yang belum merata, tingkat kesejahteraan yang masih rendah, maupun guru yang mengajar di luar bidang keahliaanya (mismacth). Data menunjukkan bahwa banyak guru dan tenaga kependidikan yang "salah kamar" dan memiliki kualitas keilmuan yang tidak memadai (unqualified atau underqualified). Hanya sekitar $20 \%$ dari total guru yang layak (qualified), 20\% mismatch dan 60\% belum atau tidak layak (Hasbullah, 2006:152).

E. Mulyasa (2008b: 10) mengidentifikasi terdapat empat faktor keterpurukkan mutu guru yaitu (1) masih banyak guru yang tidak menekuni profesinya secara utuh disebabkan rendahnya tingkat kesejahteraan; (2) belum adanya standar profesional guru sebagaimana tuntutan di negara-negara maju; (3) kemungkinan adanya perguruan tinggi swasta yang mencetak guru asal jadi, atau setengah jadi, tanpa memperhitungkan outputnya kelak di lapangan; dan (4) kurangnya motivasi guru dalam meningkatkan kualitas diri karena guru tidak dituntut untuk meneliti sebagaimana dosen di PT. Secara spesifik, mutu guru demikian akhirnya menimbulkan efek domino terhadap proses dan mutu pembelajaran di sekolah. Dalam hubungan ini, misalnya, terdapat tujuh kesalahan yang sering dilakukan guru dalam pembelajaran yaitu (a) mengambil jalan pintas dalam pembelajaran; (b) menunggu peserta didik berperilaku negatif; (c) menggunakan destructive discipline; (d) mengabaikan perbedaan peserta didik; (e) merasa paling pandai; (f) tidak adil/diskriminatif; dan (g) memaksa hak peserta didik (E. Mulyasa, 2008a: 20).

\section{Agen Pembelajaran}

Beberapa masalah yang dihadapi guru tersebut di atas tentu akan menimbulkan dampak kurang baik bagi proses pembelajaran maupun mutu pendidikan karena dalam kegiatan pembelajaran, guru memegang peranan yang sangat penting dan menentukan. Jika diibaratkan sebuah mesin (engine), guru merupakan "generator" yang akan mempengaruhi serta menggerakkan komponen-komponen lainnya (seperti peserta didik, bahan pembelajaran, metode, media, dan sarana prasarana pendukung lainnya). Di tangan gurulah keberhasilan aktivitas pembelajaran dipertaruhkan. Pembelajaran pada hakikatnya tidak lain dari seluruh interaksi edukatif yang berlangsung di sekolah baik antara guru dengan siswa, guru dengan guru, siswa dengan siswa, siswa dan guru dengan kepala sekolah, siswa dengan karyawan sekolah, bahkan hubungan siswa dengan sarana prasarana, media dan lingkungan di sekolah. Tetapi yang paling pokok, interaksi edukatif tersebut terutama berlangsung antara guru dan siswa.

Sekolah sebagai representasi pendidikan formal pada hakikatnya berintikan interaksi edukatif antara pendidik (guru) dan peserta didik (siswa). Pembelajaran, dengan demikian, merupakan kegiatan utama di sekolah. Pembelajaran adalah serangkaian peristiwa yang mempengaruhi pembelajar (siswa) dimana aktivitas tersebut berlangsung (Gagne et al, 1992: 3). G. Tharp et al (2000: 1) menjelaskan bahwa pada dasarnya semua upaya perubahan terhadap sekolah bermuara pada satu hal yakni perbaikan kegiatan pembelajaran (instructional activity) baik menyangkut masalah keuangan sekolah, ukuran kelas, penempatan guru, tujuan dan standar pendidikan nasional, kerjasama dengan masyarakat, atau aspek lain dari pendidikan. Dengan kata lain, penggunaan semua sumberdaya dan aktivitas yang ada di sekolah maupun di luar sekolah sejatinya diharapkan dapat mendukung keberhasilan dan pencapaian tujuan 
pembelajaran siswa di kelas. "Kelas" di sini, seperti diingatkan lebih lanjut oleh G Tharp et al, bukan dalam pengertian sempit secara fisik, melainkan "... in sense of the organized instructional activities that may extend outside the school building and even into the community."

Akan tetapi, sebagaimana halnya sekolah sebagai sistem yang bersifat terbuka (Pidarta, 2004: 24), maka kegiatan pembelajaran pun tidak dapat berjalan sendiri tanpa dipengaruhi oleh faktor-faktor lain. Oleh karena itu, proses dan efektivitas kegiatan pembelajaran turut ditentukan dan dipengaruhi oleh beberapa faktor yaitu: pertama, adanya tujuan yang hendak dicapai. Pembelajaran merupakan kegiatan yang dilakukan secara sengaja, sadar, dan sistematis; karena itu, agar berlangsung efektif maka ia harus direncanakan. Menurut Gagne et.al (1992: 4), perencanaan itu penting karena setiap peristiwa di kelas menuntut guru untuk mengambil satu atau beberapa keputusan. Adanya rumusan tujuan akan membantu memudahkan guru dan siswa mencapai tujuan yang telah ditetapkan. Kedua, siswa. Pembelajaran tidak lain bertujuan membantu mengembangkan secara optimal bakat, hobi, maupun fisik dan lingkungan sosial setiap individu (Gagne et al, 1992: 4). Oleh karena itu, siswa merupakan subjek utama dalam pembelajaran. Sebagai subjek, kondisi dan kesiapan siswa sangat menentukan keberhasilan pembelajaran. Secara internal, faktor-faktor tersebut antara lain minat, tujuan yang jelas, kondisi fisik (lelah, sakit, cacat); sedangkan faktor eksternal adalah keharmonisan keluarga, kondisi ekonomi, suasana lingkungan, kelengkapan sarana prasarana belajar, dan adanya penghargaan.

Ketiga, guru. Guru merupakan agen utama kegiatan pembelajaran dan karenanya sangat menentukan corak, proses, dan keberhasilan kegiatan pembelajaran. Karena posisinya yang strategis tersebut, maka guru dituntut memiliki beberapa kompetensi seperti kompetensi akademik, profesional, kepribadian, dan sosial. Kompetensi-kompetensi tersebut diperlukan terutama berkaitan dengan metode mengajar. Salah satu ciri guru yang profesional adalah terampil dalam menggunakan berbagai metode, media, dan alat dalam pembelajaran. Keempat, sarana dan prasarana. Ketersediaan dan kelengkapan sarana dan prasarana, di samping memudahkan pencapaian pembelajaran juga dapat memberikan efisiensi dan efektivitas kegiatan pembelajaran baik dari segi waktu, jarak, dan biaya. Kelima, materi/bahan pelajaran dan waktu. Isi, muatan, dan bobot materi pelajaran juga mempengaruhi kegiatan pembelajaran. Demikian juga dengan alokasi waktu yang tersedia. Semakin banyak materi pelajaran yang diajarkan tentu semakin banyak alokasi waktu yang dibutuhkan.

Keenam, kultur dan lingkungan sekolah, yakni keseluruhan suasana dan proses interaksi antarwarga sekolah seperti rasa aman, nyaman, dan pola hubungan baik antara guru dengan guru, guru dengan siswa, hubungan sesama siswa maupun interaksi antar stakeholder sekolah lainnya. Sedangkan lingkungan fisik sekolah yang indah, bersih, aman, dan nyaman dapat membangkitkan kegairahan dalam proses pembelajaran. Demikian pula dengan pola interaksi warga sekolah yang demokratis, adil, toleran dan saling menghargai dapat mempengaruhi suasana dan proses pembelajaran di kelas. Sebagaimana agen utama proses pembelajaran maka guru "... may play an essential role in the arrangement of any of these events" (Gagne et al, 1992: 3). Oleh karena itu, perencanaan pembelajaran yang dibuat oleh guru tidak semata diarahkan untuk mengembangkan potensi-potensi individu siswa yang memiliki kemiripan atau kesamaan tapi juga mampu mengakomodir dan mengelola perbedaan potensi di kalangan siswa (Gagne et al, 1992: 4), termasuk perbedaan fisik dan mental. Sebab, dalam mengajar seorang guru dihadapkan kepada keragaman karakteristik, kemampuan dan dinamika perkembangan siswa (Sukmadinata, 2007: 442).

\section{SIMPULAN DAN SARAN}

\section{A. Simpulan}

Guru adalah komponen utama dalam pembelajaran dan akan memengaruhi berbagai komponen lainnya. Oleh karena itu peningkatan mutu maupun penciptaan kultur dan menumbuhkan dedikasi guru tidak sekadar kebutuhan tapi keharusan. Sebagai investasi jangka panjang maka peningkatan mutu guru dan sekolah memang tidak langsung kelihatan hasilnya, tapi jelas sangat strategis karena akan turut menentukan masa depan sebuah bangsa. Pendidikan adalah kunci dan pertaruhan eksistensi bangsa. 
B. Saran

Untuk meningkatkan kualitas penelitian ini maka diberikan saran kepada Guru agar dapat meningkatkan kompetensi dan kualitasnya berkaitan dengan teknik pengajaran, ketersediaan perangkat pembelajaran, yang secara tidak langsung dapat meningkatkan mutu pendidikan dan dapat menjawab tantangan pendidikan di era 4.0.

\section{DAFTAR RUJUKAN}

A'la, Miftahul. 2012. Quantum Teaching (Buku Pintar dan Praktis). Yogyakarta: DIVA Press

Aman.2011. Model Evaluasi Pembelajaran Sejarah. Yogyakarta: Penerbit Ombak.

Arifin, A., Ma'ruf, F., \& Yasin, I. (2020). Efektivitas Belajar Al-Qur'an Dengan menggunakan Aplikasi Hijaiyah Berbasis Budaya Lokal "Nggahi Mbojo" (Bahasa Bima) Pada Lansia di Kabupaten Dompu. Ainara Journal (Jurnal Penelitian Dan PKM Bidang Ilmu Pendidikan), 1(1), 24-30. https://doi.org/10.54371/ainj.v1i1.10

Ma'ruf, F. (2021). Pengembangan Game Edukasi Berbasis Flash Sebagai Sarana Belajar Siswa PAUD. Ainara Journal Uurnal Penelitian Dan PKM Bidang Ilmu Pendidikan), 2(3), 143-147. https://doi.org/10.54371/ainj.v2i3.68

Arifin, Daeng. Satuan Perkualihan Seminar Masalah-Masalah Pendidikan. Bandung: PPS Uninus, 2007.

Departemen Pendidikan Nasional. Rencana Strategis Departemen Pendidikan Nasional 2005-2009. Jakarta: Depdiknas, 2005.

E. Mulayasa. Menjadi Guru Profesional. Bandung: Rosdakarya, 2008a.

E. Mulyasa. Standar Kompetensi dan Sertifikasi Guru. Bandung: Rosdakarya, 2008b.

Gagne, Robert. M. et.al. Principles of Instructional Design. Fourth Edition. Orlando: Harcourt Brace Jovanovich College Publisher, 1992.

Hasbullah. Otonomi Pendidikan. Jakarta: PT. Raja Grafindo Persada, 2006.

Pidarta, Made. Manajemen Pendidikan Indonesia. Jakarta: Rineka Cipta, 2004.

Peraturan Pemerintah No. 19 Tahun 2005 Tentang Standar Nasional Pendidikan.

Peraturan Pemerintah No. 74 Tahun 2008 Tentang Guru.

Peraturan Menteri Pendidikan Nasional No. 16 Tahun 2007 Tentang Standar Kualifikasi Akademik dan Kompetensi Guru.

Sukmadinata, Nana Syaodih. Pengembangan Kurikulum Teori dan Praktik. Bandung: Rosdakarya, 2008.

Tharp.RG. et. al. Teaching Transformed. USA: Westview Press, 2000.

Undang-Undang RI No. 20 Tahun 2003 Tentang Sistem Pendidikan Nasional.

Undang-Undang RI No. 14 Tahun 2005 Tentang Guru dan Dosen. 